\title{
Anaerobic Co-Digestion of Fish Processing Waste with Cow Manure and Waste of Market (Rests of Fruits and Vegetables): A Lab Scale Batch Test
}

\author{
Ndèye Ndickou Kébé1, Christiane Rieker², Papa Abdoulaye Fall³, Djicknoum Diouf ${ }^{1}$, \\ Diène Ndiaye1, Thomas Mockenhaupt², Patrick Beuel2, Jamile Bursche²
}

${ }^{1}$ Laboratory of Electronics, Computer Science, Telecommunications and Renewable Energy, Gaston Berger University, Saint-Louis, Senegal

${ }^{2}$ CIRE (Cologne Institute for Renewable Energy) Bioenergy, University of Apllied Sciences of Cologne TH Köln, Cologne, Germany ${ }^{3}$ Dakar, Senegal

Email: kebendickou@gmail.com, djicknoum.diouf@ugb.edu.sn, diene.ndiaye@ugb.edu.sn, christiane.rieker@th-koeln.de, thomas.mockenhaupt@th-koeln.de,patrick.beuel@th-koeln.de, jamile.bursche@th-koeln.de,vieuxfall@yahoo.com

How to cite this paper: Kébé, N.N., Rieker, C., Fall, P.A., Diouf, D., Ndiaye, D., Mockenhaupt, T., Beuel, P. and Bursche, J. (2021) Anaerobic Co-Digestion of Fish Processing Waste with Cow Manure and Waste of Market (Rests of Fruits and Vegetables): A Lab Scale Batch Test. Journal of Sustainable Bioenergy Systems, 11, 45-59.

https://doi.org/10.4236/jsbs.2021.111004

Received: December 3, 2020

Accepted: March 23, 2021

Published: March 26, 2021

Copyright (C) 2021 by author(s) and Scientific Research Publishing Inc. This work is licensed under the Creative Commons Attribution International License (CC BY 4.0).

http://creativecommons.org/licenses/by/4.0/ (c) (i) Open Access

\begin{abstract}
The aim of this work was to use fish processing waste (FW) as main substrate for anaerobic digestion. To enhance the biogas production of FW, co-digestion was done with two other substrates: cow dung (CD) and waste of market (MW). Batch test was carried out in an $1 \mathrm{~L}$ glass digester in a temperature controlled chamber at $38^{\circ} \mathrm{C}$. The following mixtures were carried out: $\mathrm{FW}$ with CD respectively at different ratios 100:0\% (A), 80:20\% (B) and 60:40\% (C); FW with $\mathrm{MW}$ at the following ratio 80:20\% (D); FW with $\mathrm{CD}$ and MW respectively at these ratios $80: 10: 10 \%(\mathrm{~F})$ and $60: 20: 20 \%(\mathrm{G})$. The biogas produced was measured using a milligas counter ${ }^{\circledR}$ and the volume of gas was recorded. The gas composition was determined using gas chromatography. With a $\mathrm{pH}$ stable for raw substrates and mixtures, TS and VS (\%TS) contents for FW were respectively $31.01 \%$ and $91.55 \%$. Between 3 to 13 days of experimentation, the highest flow rate was observed. The percentage of methane was more important for mixtures $\mathrm{B}$ and $\mathrm{D}, 61 \%$ and $59 \%$ respectively. $\mathrm{pH}$ and VOA/TIC were stable at the end of the batch test for all mixtures, meaning that the organic matter was already well digested. The highest values of Volatile Solid Removal (VSR) were found for mixtures $\mathrm{C}, \mathrm{D}, \mathrm{F}$ and $\mathrm{G}$. Therefore, the promising mixtures for next experimentations in large scale are $\mathrm{B}$ and $\mathrm{D}$.
\end{abstract}

\section{Keywords}

Fish Waste, Batch Test, Co-Digestion, Flow Rate, Organic Matter 


\section{Introduction}

The food crisis caused by years of drought leads to the intensive practice of the fishing season in Senegal. Global fish production was 167 millions tons in live weight in 2014. Of this $87.5 \%$ were intended for human consumption and the remaining $12.5 \%$ for fish oil and meal production [1]. About $70 \%$ of fish are processed before being sold. $20 \%$ to $80 \%$ of this total is fish processing waste, depending on the type of processing and the species processed [2]. This waste has significant potential for the production of biogas through anaerobic digestion.

In our previous work, the potential of production of methane of fish wastes showed a production of biogas of $9.67 \mathrm{~m}^{3}$ for fish waste alone $(2970 \mathrm{~kg})$ in a digester of $10 \mathrm{~m}^{3}$ of volume [3]. This study was carried out within the framework of feasibility technical, social and organisational of the project of installation of digesters to the site of processing the halieutics products of Hydrobase, in Saint-Louis. This study revealed that fish processing waste could indeed produce biogas. However, to better understand the behavior of such substrate in anerobic digestion, physicochemical characterizations were carried out during this research. But also, a co-digestion of this substrate was done, i.e. the combination of this substrate with one or more other substrates to increase the production of biogas.

At the beginning of 2018, literature on the anaerobic digestion of fish and fish waste was still rather sparse, about 20 research papers on this issue. Existing studies showed that digestion and co-digestion of fish waste both have considerable potential for producing biomethane [1].

As an advantage, biogas production from fish processing waste contributes to reducing the volume of fish waste and cost of waste disposal and reduces waste odor by $80 \%$ [4]. In addition, by the anaerobic digestion, the significant amount of methane gas emission resulting from the uncontrolled anaerobic decomposition of organic waste into the atmosphere would be also reduced [5]. The biogas generated from fish wastes would be used to produce heat for fish smoking, drying and preservation. As a result, the cost of fish processing, preservation and storage would decrease. The innovation of fish biogas production or fish waste bio digestion would tremendously help the environment in fishing communities. Because the world is under the treat by the ozone layer depletion due to much carbon burning and drastic depletion of the global forest vegetation for firewood [6]. If all fishermen and fish farmers in every fishing community will embrace fish waste bio digestion to produce biogas (methane) which can be used in fish processing and preservation, they will spend less money on heat generation. Reducing consumption of forest biomass will be a very good tool for creating sustainable forestry resources for the future [4].

The results of the latest works show that fish processing waste in general contains high concentrations of fat and protein, and there is a large risk for accumulation of fatty acids and $\mathrm{NH}_{3}$ (ammoniac) when these types of substrates are anaerobically digested ([7] [8] [9] [10]. One way to overcome the problems with 
anaerobic digestion of protein and lipid rich waste materials (energy-rich materials) is to use a mixture of substrates with different properties. Co-digestion may improve the anaerobic digestion process, by creating a better nutrient balance, diluting toxic compounds, and stimulating synergistic effects of microorganisms and possibly also increase the stability of the system and the methane production [11].

For this purpose, in this work anaerobic digestion of fish waste will be investigated in order to determine the physico chemical characteristics of this type of substrate. Also, co-digestion of fish waste with cow dung and waste of market (fruits and vegetables) were conducted to improve the results of digestion with fish waste alone.

\section{Material and Methods}

\subsection{Experimental Procedure (Batch Test)}

The batch tests were performed according to standard VDI 4630 [12]. Batch test reactors consisted in a system composed of:

- bottles of $1000 \mathrm{~mL}$ of volume which represent the digester;

- condensator: a small bottle to collect the water which can come from the digester;

- a milligas counter to measure the volume of produced gas and;

- a bag of storage for each bottle, which can allow to analyse the produced gas later.

The bottles were stirring manually every day for avoiding gas concentration into the bottles. The diagram below is the diagram of the representation of the batch test (Figure 1).

The substrates were put into the flasks of $1000 \mathrm{ml}$, for fermentation and production of biogas. The flasks are then closed and connected to the milligas

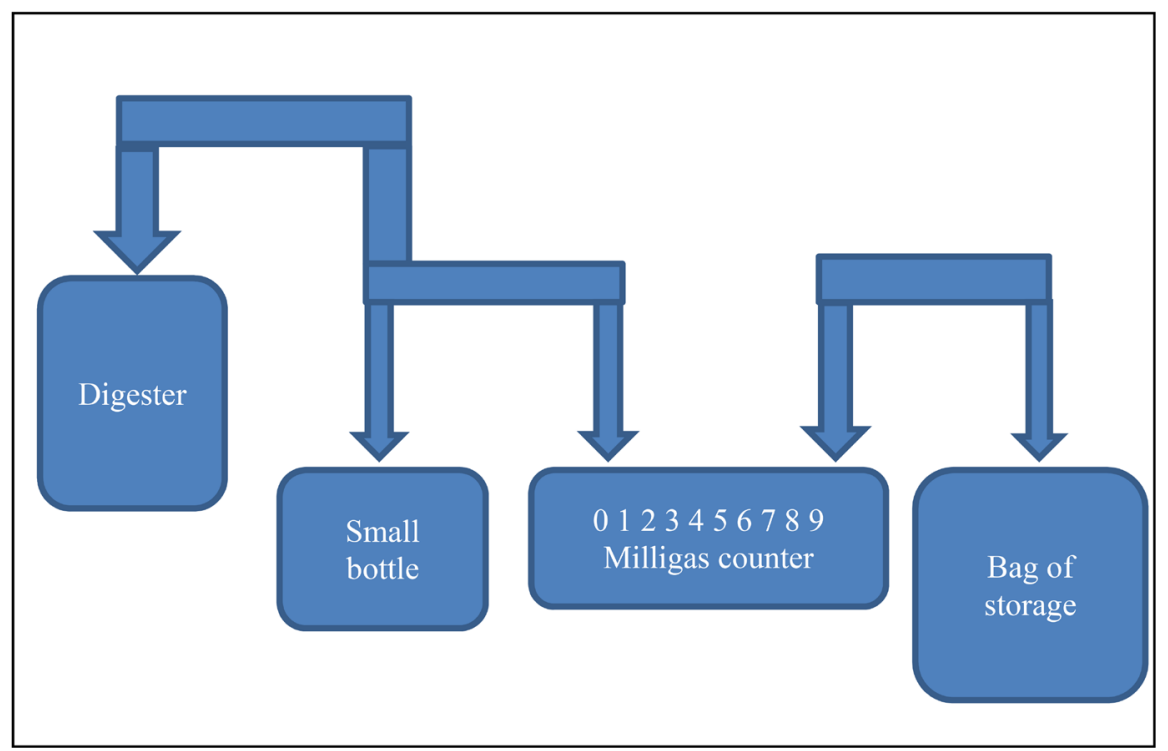

Figure 1. Representation of the batch test. 
counter by hoses. When a gas is produced, the milligas counter gives us the amount of produced gas. The bag of storage serves to store the gas and to analyze it later. The small bottle downstream the digester serves to collect the water which could come from the digester due to the pressure of gas produced.

To prevent inhibition in the fermentation batch, the substrate should not be overlage in proportion to the inoculum. The following inequality applied:

$$
\mathrm{VS}_{\text {substrate }} \leq 0.5 * \mathrm{VS}_{\text {inoculum }}[12]
$$

where $\mathrm{VS}_{\text {substrate }}$ and $\mathrm{VS}_{\text {inoculum }}$ are respectively the volatile solid content of the substrate and the inoculum.

For our experimentation, we have adopted a hydraulic retention time of 35 days, and a mesophilic system with a temperature of $39^{\circ} \mathrm{C}$ for all the process. The process is stopped when there is less than $0.5 \%$ new gas formation during 3 days [12].

For homogenizing the substrates, fish processing waste and the waste of market were mixed separately with a blender kitchen and were kept into the freezer at $-20^{\circ} \mathrm{C}$ for further analyzes.

\subsection{Substrates and Inoculum}

\section{Substrates}

Fish processing waste is our main substrate for the batch test. It was collected at the market of Bad Honnef in Germany and comes from the sea. It consists of heads, gills, viscera and non-fresh fish. Fish wastes are mixed with a blender kitchen to homogenize them before the experimentation.

Fish processing waste is a substrate rich in protein, and its nitrogen content is high and can inhibit the digestion process. It is also a substrate rich in lipids. In fact, waste lipids are ideal substrates for methane production since their degradation does theoretically produce more biogas $(1.42 \mathrm{~L} / \mathrm{g})$ than proteins or carbohydrates ( 0.92 and $0.83 \mathrm{~L} / \mathrm{g}$, respectively) [13]. To enhance the biogas production of fish processing wastes, and to have a high quality of gas, with less sulphide hydrogen $\mathrm{H}_{2} \mathrm{~S}$, and pollutants, and to balance the proportion of nitrogen, we have done co-digestion. Co-digestion is a fermentation with more than one susbtrate. The other susbtrates are called co-substrates. They are raw materials for fermentation which are not the raw material with the highest percentage share of the total material flow to be fermented [12] (it means that the percentage of fish processing wastes is higher than the percentages of the other substrates).

As co-substrates, waste of market and manure were used during this investigation. The waste of market is composed of peelings of fruits and vegetables, like carrots, cabbages, beets, potatoes, lettuce, banana, apple, orange and pear. The manure (prepared with cow dung) was taken from the second reactor of a biogas plant close to Overtah in Germany, working in mesophilic range. Most of the solid content of the manure is already degraded. The wastes of market are also mixed with a blender kitchen to homogenize them. 


\section{Inoculum}

To accelerate the formation of bacterias for anaerobic digestion, an inoculum is always used. For the batch test, our inoculum is a cow dung from a digester which works in mesophilic condition, stored for 7 days at $37^{\circ} \mathrm{C}$ as recommended by VDI 4630 [12].

\subsection{Co-Digestion (Different Mixtures)}

The batch test was conducted with different proportions of the substrate (FW) and co-substrates (MW and CD). For this, flaks of $1000 \mathrm{ml}$ were used with a working volume not above $800 \mathrm{ml}(80 \%)$, to avoid head space into the flask and formation of foam during the process. For all the flasks, the volume of the inoculum is constant, $700 \mathrm{ml}$.

The compositions of the substrates into the flasks are varying depending on the mixture of raw materials: fish waste (FW), cow dung or manure (CD) and market waste $(\mathrm{MW})$. We have then the following mixtures FW:CD - FW:MW and FW:CD:MW, on wet weight basis.

- First fish wastes were mixed with cow dung on ratios of 100:0\% (A), 80:20\% (B), 60:40\% (C), from fish waste and cow dung respectively.

- Secondly, fish waste mixed with waste of market on ratio of 80:20\% (D), from fish waste and market waste respectively.

- And finally, fish waste, cow dung and waste of market mixed on ratios of 80:10:10\% (F) and 60:20:20\% (G), from fish waste, cow dung and waste of market respectively.

A blank containing only the inoculum was also digested in a flask. The effective volume of biogas produced for each mixture will be given by withdrawing the volume of gas produced by each mixture from the volume produced by the blank.

Based to relation (1) as proposed in German standard procedure [12], the mass of the substrates and inoculum which were put in each bottle, were determined and are presented in Table 1. For some reactors, there is surplus of volume of inoculum, due to the method of measurement.

Table 1. Volume of inoculum and substrate put in each reactor during the batch test (S/I ratio based on VS content).

\begin{tabular}{cccc}
\hline $\begin{array}{c}\text { Mixtures } \\
\text { (\% wet weight) }\end{array}$ & $\begin{array}{c}\text { Volume of inoculum } \\
(\mathrm{mL})\end{array}$ & $\begin{array}{c}\text { Mass of substrate } \\
(\mathrm{g})\end{array}$ & $\begin{array}{c}\text { Ratio substrate/inoculum } \\
\text { S/I (VS/VS) }\end{array}$ \\
\hline A & 713.98 & 56.32 & 1.78 \\
B & 765.64 & 40.98 & 1.26 \\
C & 701.18 & 58.32 & 1.90 \\
D & 702.47 & 20.62 & 0.59 \\
F & 704.265 & 23.795 & 0.71 \\
G & 701.7 & 32.35 & 0.99 \\
\hline
\end{tabular}


The waste to inoculum ratio $S / I$ was calculated based on the initial VS of the substrate and inoculum:

$$
\frac{S}{I}=\frac{\text { substrate added }(\mathrm{gVS})}{\text { inoculum added }(\mathrm{gVS})}
$$

Higher amounts of inoculum resulted in higher concentrations of VFA, causing a reduction of the biogas yield. The maximum specific biogas production could be obtained using the minimum amount of inoculums [14].

The waste to inoculum ratio is more important for mixtures $\mathrm{A}, \mathrm{B}$ and $\mathrm{C}$, equal to around 2. For mixtures $\mathrm{D}, \mathrm{F}$ and $\mathrm{G}$, it is equal to around 1 . At the laboratory scale, S/X ratios between 2 and 6 (in VS basis) are typically used, suggesting that $\mathrm{S} / \mathrm{X}$ ratio actually applied in industry can be optimized [15].

\subsection{Different Parameters Measured}

For anaerobic digestion, different parameters such as temperature, $\mathrm{pH}$, etc have to be followed to avoid inhibition due to evaluate the fermentation process.

- $\mathrm{pH}$ : For each mixture we have measured the $\mathrm{pH}$. The $\mathrm{pH}$ optimum of hydrolysing and acid-forming bacteria is in a range from $\mathrm{pH} 5.2$ to 6.3, for example. In contrast, a $\mathrm{pH}$ value in the neutral range from 6.5 to 8 is absolutely essential for the bacteria that form acetic acid and for the methanogenic archaea that would be ranged between 6.5 and 8 for all the anaerobic digestion process [16].

To measure the $\mathrm{pH}$ for one mixture, $10 \mathrm{~g}$ of substrate were mixed with $40 \mathrm{~g}$ of distilled water in a $1 \mathrm{mml}$ beaker. Before measuring the $\mathrm{pH}$ values, the $\mathrm{pH}$-meter was calibrating using commercial buffers for $\mathrm{pH} 4.0$ and 7.0. After equilibration, the $\mathrm{pH}$ was measured using a WTW-MULTI 3630 IDS device.

The conductivity can be also measured with this device.

- TS and VS: For the total solid (TS) and the volatile solid contents (VS), measurments were done in triplicate. For that, the empty crucible porcelain, where the samples will be put, were weight. After that, 3 grammes of substrate were put into the crucible porcelain, and we weight the unit. We put then the units (sample + porcelain) into the oven, for 12 hours at least, on to $105^{\circ} \mathrm{C}$. After the 12 hours, the units were removed from the oven, and were put into the dessicator for 15 minutes, to protect them against moisture. Then the new weight of the units was measured and the total solids of the samples was calculates.

To calculate the volatile solids (VS), i put again the porcelain + sample into the oven for 5 hours on to $550^{\circ} \mathrm{C}$. Then, the units were removed from the oven, and put, for 1 hour, into the oven on to $105^{\circ} \mathrm{C}$ (for cooling them).

Therefore, when the temperature of the units decreases, they were put into the dessicator for 15 minutes. After that, the units were weight to determine the VS of our substrates.

TS and VS were measured according to APHA standard methods.

- Alkalinity, expressed in our measure by VOA/TIC values (Volatile Organic 
Acid/Total Inorganic Carbon). VOA means the concentration of fatty acids and TIC the buffer capacity. This parameter informs us about the degradability of substrates during anaerobic digestion [17]. There are 3 critical values for this [18] [19]:

- If this value is lower than 0.4 the digester should be stable.

- While, when the ratio ranged $0.4-0.8$, some instability will occur on the digester performances.

- However, the ratio higher than 0.8 , indicates a significantly instability.

- Volatile fatty acids (with HPLC High Pressure Liquid Chromatograph)

To investigate the fermentations process, the chemical composition of sub-trates was analyzed using a high-performance liquid chromatograph with a Rezex $^{\mathrm{TM}}$ ROA Column (Phenomenex LTD, Germany), refractive index detector (RID 10A, Shimadzu Europa $\mathrm{GmbH}$ ) at $60^{\circ} \mathrm{C}$ with a flow rate of $0.6 \mathrm{ml} \cdot \mathrm{min}^{-1}$ and $5 \mathrm{mM} \mathrm{H}_{2} \mathrm{SO}_{4}$ as eluent [20].

\section{- Ammonium}

To measure ammonium content of substrates, fresh samples were taken and 50 grammes for each of them were measured and put into plastic bags. After, 200 grammes of water were put in each of them. After that, they were put into the masticator for 4 minutes to mix the solution (working on 80 strokes/s). After that the distillate was then collected. A $200 \mu \mathrm{L}$ from each sample was taken and put into ammonium solution. Then we wait 15 minutes, and we do the measurment only if there is a colouring.

\section{- Total organic carbon (TOC)}

The measurment was done with dried and crushed sample (samples were dried into the oven on to $50^{\circ} \mathrm{C}$ and crushed to reduce the size and obtain a substance like powder). After that, till $0.2 \mathrm{~g}$ were put into the crucible in triplicate.

A chlorhydric acid solution ( $\mathrm{HCl} \mathrm{10 \% )} \mathrm{was} \mathrm{put} \mathrm{into} \mathrm{each} \mathrm{of} \mathrm{them,} \mathrm{then} \mathrm{a} \mathrm{solu-}$ tion of chlorhydric acid ( $\mathrm{HCl} 37 \%)$.

Then, the units were put into the oven to dry them during 3 hours on $105^{\circ} \mathrm{C}$.

After that, the device analytik Jena multi N/C 2100S was used to measure the TOC.

- Gas composition using a gas chromatograph

The gas composition of our samples was determined at the end of the experimentation with a gas chromatograph. For example for the sample A, an amount of gas from the bag storage was exctracted with a syringe, and injected into the gas chromatograph. Then, the device draws a chromatograph which can be visualized on a screen. And after the percentage of each gas that compose biogas was calculated. This process was repeated for all the samples.

\section{Results and Discussion}

Results of measurements of total solids (TS), volatile solid (VS), $\mathrm{pH}$ and VOA/TIC for raw substrates (fish waste, waste of market and cow dung) are given in Table 2. 
As shown in Table 1, the solid content (TS) of fish waste is $31.01 \%$, and among which $91.55 \%$ was represented by biologically degradable materials which is VS. Kafle and al., 2012a [21] found around the same values compared to our study: $31.3 \%$ for TS content of fish waste and $88 \%$ for VS content. Chen and al., 2010 [22] reported very high VS/TS ratio of fish waste compared to our work.

The low percentage of TS content for cow dung is due to the fact that it contains a considerable amount of water. For market waste, we have the same content as fish waste.

The FW contained very high amount of protein $(40.9, \%$ TS) and fat $(48.9, \%$ TS), thus, it is expected to obtain much higher methane yield than animal manure [23]. The theoretical yield for fat (lipids) is about $1000 \mathrm{~mL} / \mathrm{g} \mathrm{VS}$, and for protein is about $480 \mathrm{~mL} / \mathrm{g} \mathrm{VS}$, while the theoretical yield for carbohydrate is about $375 \mathrm{~mL} / \mathrm{g}$ VS (VDI 4630, 2016).

For all the mixtures, high rate of VS inside TS content was obtained, because mixtures are composed of more fish waste (more than $60 \%$ of fish waste for all of them) (Table 3).

$\mathrm{pH}$ is also stable for all the mixtures, between 6.6 and 7.7 for mixtures B to G, and 4.2 to 8.5 for raw substrates. Kassuwi and al., 2012 [24] reported a pH range of $7.10 \pm 0.2$ for fish solid waste and $5.66 \pm 0.06$ for market wastes.

At the end of the experiment, the VOA/TIC for cow dung was equal to 0.26. It means that this substrate was already degraded. There are less bacteria in this substrate, because it comes from a digester which has already produced its biogas. For mixtures $\mathrm{F}$ and $\mathrm{G}$, and fish waste, VOA/TIC was more than 0.75 . There are more substrates in these mixtures, $\mathrm{pH}$ would be decreased and it would lead

Table 2. Characteristics of raw substrates.

\begin{tabular}{ccccc}
\hline Substrate & TS (\%) & VS (\%TS) & pH & VOA/TIC \\
\hline Fish waste (A) & 31.01 & 91.55 & 6.9 & 1.56 \\
Cow dung & 5.91 & 77.15 & 8.5 & 0.26 \\
Market waste & 14.41 & 92.33 & 4.2 & $\mathrm{Nd}^{\mathrm{a}}$ \\
\hline
\end{tabular}

aNd means "not detected".

Table 3. Characteristics of mixtures.

\begin{tabular}{ccccc}
\hline Substrate & TS (\%) & VS (\%TS) & pH & VOA/TIC \\
\hline B & 28.13 & 86.71 & 7.3 & 0.8 \\
C & 22.10 & 90.31 & 7.7 & 0.5 \\
D & 27.19 & 93.68 & 6.6 & $\mathrm{Nd}^{\mathrm{a}}$ \\
F & 26.11 & 91.72 & 7 & 3.5 \\
G & 19.28 & 92.76 & 7 & 7.39 \\
\hline
\end{tabular}

${ }^{\mathrm{a} N d}$ means "not detected". 
to inhibition of the system. For mixtures B and C, it can be said that the process would be stable during anaerobic digestion. Because it is composed of fish waste and cow dung already digested and the association of these two substrates makes it possible to activate the bacteria contained in the cow dung.

As seen in Table 4, the only sugar which was detected for raw substrates was glucose (a monosaccharid) with around the same quantity for fish waste, market waste and cow dung.

However, ammonia was contained in these raw materials with a largest quantity for cow dung. But, this value does not exceed the margin (inhibitory concentration when $>3.500 \mathrm{mg} / \mathrm{l} \mathrm{NH}_{4}^{+}$at $\mathrm{pH}$ equal to 7 [16]).

Ammonia is the result of the reaction of ammonium with water. In fact, the total ammonia nitrogen and VFAs both are important intermediates and potential in the anaerobic digestion process [18]. High concentration of ammonia and VFAs in the digester would decrease the methanogen activity and further accumulation could inhibit the anaerobic digestion [25] (Table 5).

Fish waste releases high levels of ammonia when digested, which inhibit the digestion of substrates. High concentrations of ammonia can result in the accumulation of VFAs (acetic acid as the main type in the batch test) [1].

Ammonia content for all the mixtures (A to $\mathrm{G}$ ) is acceptable and does not exceed the margin.

However, sugars are mainly present into the mixtures D and G, which are composed of fish wastes and market wastes in variable proportions. These sugars are glucose, xylose and arabinose. Kassuwi and al. [24] reported that market wastes collected from food market, essentially contain sugars and hemicelluloses

Table 4. Ammonia, sugar contents for raw materials.

\begin{tabular}{|c|c|c|}
\hline Samples & Ammonia content $\left(\mathrm{mg} / \mathrm{L} \quad \mathrm{NH}_{4}^{+}-\mathrm{N}\right)$ & Glucose $(\mathrm{mg} / \mathrm{L})$ \\
\hline Fish waste & $\mathrm{Nd}$ & 9.62 \\
\hline Cow dung & 0.04 & 9.26 \\
\hline Market waste & 22.9 & 9.61 \\
\hline
\end{tabular}

aNd means "not detected".

Table 5. Ammonia, sugar and VFA contents of substrates for mixtures.

\begin{tabular}{ccccccc}
\hline Samples & $\begin{array}{c}\text { Ammonia content } \\
\left(\mathrm{mg} / \mathrm{L} \quad \mathrm{NH}_{4}^{+}-\mathrm{N}\right)\end{array}$ & $\begin{array}{c}\text { Glucose } \\
(\mathrm{mg} / \mathrm{L})\end{array}$ & $\begin{array}{c}\text { Xylose } \\
(\mathrm{mg} / \mathrm{L})\end{array}$ & $\begin{array}{c}\text { Arabinose } \\
(\mathrm{mg} / \mathrm{L})\end{array}$ & $\begin{array}{c}\text { Lactic acid } \\
(\mathrm{mg} / \mathrm{L})\end{array}$ & $\begin{array}{c}\text { Acetic acid } \\
(\mathrm{mg} / \mathrm{L})\end{array}$ \\
\hline $\mathrm{A}$ & $\mathrm{Nd}$ & 0 & 0 & 0 & 0.15 & 9.68 \\
$\mathrm{~B}$ & 0.053 & 0 & 0 & 0 & 0.12 & 9.65 \\
$\mathrm{C}$ & 0.275 & 0 & 0 & 0 & 0.09 & 9.97 \\
$\mathrm{D}$ & 0.056 & 0 & 0.13 & 0.59 & 0.13 & 11.01 \\
$\mathrm{~F}$ & 0.025 & 0 & 0 & 0 & 0.14 & 8.15 \\
$\mathrm{G}$ & 0.152 & 0 & 0 & 0.5 & 0.11 & 10.9 \\
\hline
\end{tabular}

aNd means "not detected". 
which are highly biodegradable with $60 \%$ - $82 \%$ volatile solids (VS) content. This encourages the rapid production of volatile fatty acids, which would lead to a rapid $\mathrm{pH}$ drop.

In a well balanced anaerobic digestion process, VFA levels are low (Chen et al., 2007, [25]). Lactic acid and acetic acid are the volatile fatty acids that mainly composed the mixtures A to G.

Total organic carbon was determined for FW, CD and MW as described previously. In Table 6, the same results are obtained for all the substrates and we noted that all the substrates are rich in carbon. Nalinga and al., 2016 [26] reported organic carbon content of $42 \%$ for water hyacinth and $53 \%$ for fish waste.

During experimentation, the volumes of produced biogas were taken every day, to know the cummulated volume of biogas of each mixture at the end of the batch test. For all the mixtures, gas generation started at the first day and continued while the end of the processus. The highest flow rate was observed between 3 to 13 days of the investigation. The same trend was observed in the study made by Tomczak-Wandzel and al., 2012 [27] with production of biogas with fish waste and sewage sludge, where the highest flow rate was observed between 7 to 12 day of the investigation. According to Carvalho and al., 2011 [28] who tested the production of biogas from fish sludge, after the first 10 days of batch essay, $81 \%$ of the total biogas was formed, and by the $20^{\text {th }}$ day $92 \%$ of it was already produced.

The greatest volumes of produced biogas were obtained with mixtures $\mathrm{D}, \mathrm{F}$ and G, with a volume of $6139.44 \mathrm{ml}$ for D. For mixtures B and C, we have less volume of biogas with $3224.44 \mathrm{ml}$ and $1593.36 \mathrm{ml}$ for $\mathrm{B}$ and $\mathrm{C}$ repectively (Figure 2).

At the end of the batch test, the gas contained into each bag storage was analysed to know its composition. All the results were expressed in percentage of volume in Table 7.

As a reminder, biogas is a gas mixture that is primarily made up of methane $\left(\mathrm{CH}_{4}\right)$ and carbon dioxide $\left(\mathrm{CO}_{2}\right)$, along with water vapour and various trace gases. The most important of these is the methane content, since this is the combustible component of biogas and thus directly influences its calorific value. [16]

For the mixtures $\mathrm{B}$ and $\mathrm{D}$, the percentage of methane is more than $50 \%$, around $59 \%$ for $\mathrm{D}$ and $61 \%$ for $\mathrm{B}$. It is good for anaerobic digestion because the quality of biogas is very important for its valorization.

Although, for the other mixtures, the required amount of methane was not obtained, but the percentage of carbon dioxyde for example is not negligible. Shi and al., 2012 [29] argue that the superfluous content of $\mathrm{CO}_{2}$ will lead to decrease

Table 6. Total organic carbon (TOC).

\begin{tabular}{cccc}
\hline Substrate & FW & CD & MW \\
\hline Total Organic Carbon $(\mathrm{g} / \mathrm{kg})$ & 297.8 std 22.31 & 265.9 std 25.10 & 284 std 24.42 \\
\hline
\end{tabular}




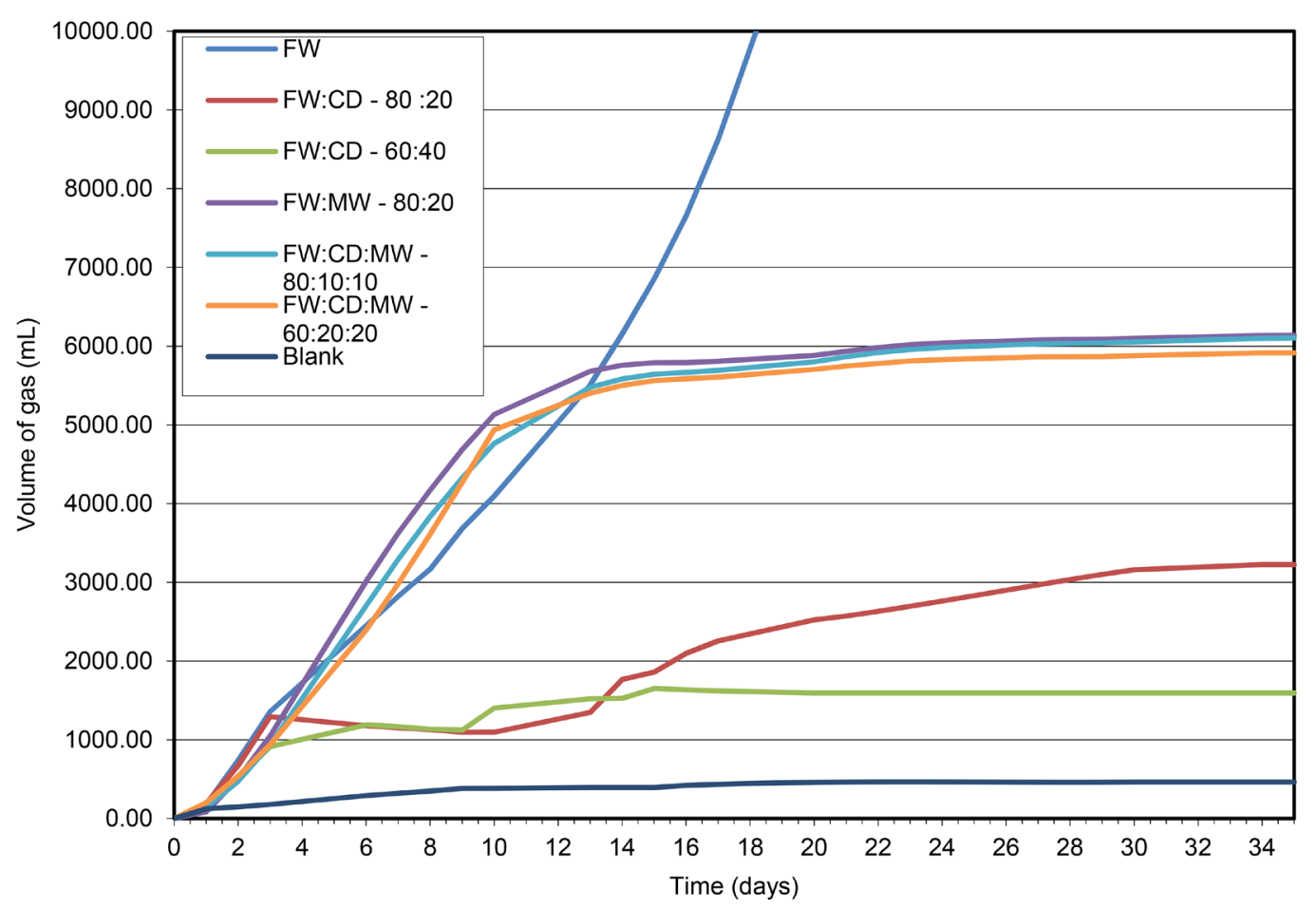

Figure 2. Cummulated volume of produced gas for each mixture.

Table 7. Gas composition of substrates.

\begin{tabular}{cccccccc}
\hline \multirow{2}{*}{$\begin{array}{c}\text { Sample } \\
\text { name }\end{array}$} & $\mathrm{H}_{2} \mathrm{~S}$ & $\mathrm{H}_{2}$ & $\mathrm{CO}_{2}$ & $\mathrm{O}_{2}$ & $\mathrm{~N}_{2}$ & $\mathrm{CH}_{4}$ & $\mathrm{CO}$ \\
\hline Blank & 0.0043 & 0.0099 & 45.9051 & 1.6095 & 3.3668 & 49.1044 & n.a. \\
A & n.a. & 0.0496 & 22.6559 & 7.677 & 41.8101 & 27.8074 & n.a. \\
B & 0.00908 & 0.0131 & 32.2873 & 3.1151 & 3.0709 & 61.5038 & n.a. \\
C & n.a. & 0.0318 & 28.7915 & 3.3968 & 19.9784 & 47.8015 & n.a. \\
D & n.a. & 0.0806 & 31.4357 & 2.9264 & 6.6263 & 58.931 & n.a. \\
F & 0.0095 & 0.0432 & 19.9155 & 10.8324 & 32.5992 & 36.6002 & n.a. \\
G & n.a. & 0.0403 & 20.4841 & 10.0963 & 32.681 & 36.6983 & n.a. \\
\hline
\end{tabular}

the $\mathrm{pH}$ level and destroy the methanogenesis process. A high concentration of $\mathrm{CO}_{2}$ might come from high temperature or clog of air outlet.

The percentage of hydrogen sulphid for all the mixtures is stable.

At the end of the batch test, TS, VS, $\mathrm{pH}$ and buffer capacity for all digestates were measured. The $\mathrm{pH}$ was stable for all the mixtures and the VOA/TIC was also stable. It could mean that the organic matter contained into the substrates is already well digested, and has already produced biogas. Total solid also decreased, meaning that the matter was degraded.

To better understand the degradability of substrates, there are some parameters which we can calculate, such as the volatile solid removal (VSR). The re- 
moved VS content could reflect the degradability of substrates and the efficiency of the digestion process to some degree. The slower growth of microorganisms did affect the decomposition of organic substances leading to lower VSR [29].

$$
\operatorname{VSR}(\%)=\left(\left(V S_{\text {in }}-V S_{\text {out }}\right) / V S_{\text {in }}\right) * 100
$$

Following the values found in Table 8, there are not higher values of VSR. However, the highest values of VSR were obtained with samples C, D, F and G. This would mean that the easily volatile component would probably diffuse into the atmosphere before measuring the VS content of samples, if many degraded organics left in the digestate after digestion [29].

Therefore, VSR could not measure the biodegradability of substance alone. (Table 9) It should combine with other methods such as the measurement of dissolve organic carbon and microorganism activity to assess the biodegradability of substrate in the anaerobic digestion [29].

\section{Conclusions}

In this work we focus on the biogas production by anerobic digestion of fish based substrates in batch test process. The criteria for judging the success of a co-digestion were process stability, VS reduction, biogas production rate and methane yield [18].

Therefore, co-digestion of fish processing waste with market waste and cow Table 8. TS, VS and $\mathrm{pH}$ of residual matter.

\begin{tabular}{ccccc}
\hline Substrate & TS (\%) & VS (\%TS) & pH & VOA/TIC \\
\hline Blank & 6.22 & 78.52 & 7.9 & 0.24 \\
A & 6.13 & 83.91 & 8 & 0.27 \\
B & 6.23 & 79.04 & 8 & 0.24 \\
C & 6.74 & 77.27 & 8.1 & 0.23 \\
D & 6.99 & 76.90 & 8 & 0.25 \\
F & 6.78 & 77.75 & 7.9 & 0.24 \\
G & 6.58 & 81.38 & 8 & 0.23 \\
\hline
\end{tabular}

Table 9. Volatile solid removal (VSR) of mixtures.

\begin{tabular}{cccc}
\hline Substrate & $V S_{\text {in }}(\%)$ & $V S_{\text {out }}(\%)$ & VSR (\%) \\
\hline A & 91.55 & 83.91 & 8.34 \\
B & 86.71 & 79.04 & 8.84 \\
C & 90.31 & 77.27 & 14.43 \\
D & 93.68 & 76.9 & 17.91 \\
F & 91.72 & 77.75 & 15.23 \\
G & 92.76 & 81.38 & 12.26 \\
\hline
\end{tabular}


dung revealed that associate fish processing waste with cow dung at ratio 80:20 is more successful in terms of biogas production (percentage of methane of $61 \%$ ). Also the association of fish waste with waste of market at ratio 80:20 is promising with a percentage of methane of $59 \%$ for the biogas produced.

Enhancing the biogas productivity of fish waste combined with these two wastes will be our next aims. However, these experimentations will be done in a large scale with the same proportion for each mixture: fish processing waste in co-digestion with cow dung and waste of market.

\section{Acknowledgements}

All scientific work has been carried out at Metabolon, the center of Research and Expertise of Cologne University of Applied Sciences.

This work has been done during our training research at the Cologne University of Applied Sciences. Internship was carried out with the financial support of the African Center of Excellence in Mathematics, Computer Science and ICT (CEA-MITIC) based at Gaston Berger University of Senegal.

\section{Conflicts of Interest}

The authors declare no conflicts of interest regarding the publication of this paper.

\section{References}

[1] Ivanovs, K., Spalvins, K. and Blumberga, D. (2018) Approach for Modelling Anaerobic Digestion Processes of Fish Waste. Energy Procedia, 147, 390-396. https://doi.org/10.1016/j.egypro.2018.07.108

[2] AMEC (2003) Management of Wastes from Atlantic Seafood Processing Operations. AMEC Earth and Environment Limited, Dartmouth.

[3] Kebe, N.N., Fall, P.A., Ndiaye, D. and Diouf, D. (2019) Residues of the Transformation of Halieutics Products: An Alternative Substrate for Energy Valorization of Wastes by Methanisation for a Local Sustainable Development (Preliminary Results). African Journal of Environmental Science and Technology, 13, 291-295. https://doi.org/10.5897/AJEST2018.2549

[4] Nnali, K.E. and Oke, A.O. (2013) The Utilization of Fish and Fish Farm Wastes in Biogas Production: A Review. Advances in Agriculture, Sciences and Engineering Research, 3, 656-667.

[5] McDermott, B.L., Chalmers, A.D. and Goodwin, A.S. (2001) Ultrasonication as a Pre Treatment Method for the Enhancement of the Psychrophilic Anaerobic Digestion of Aquaculture Effluents. Environmental Technology, 22, 823-830. https://doi.org/10.1080/095933322086180317

[6] Santana, A. and Proud, B. (1980) The Production of Biogas from Cattle Slurry, the Effects of Concentration of Total Solids and Animal Diet. Tropical Animal Production, 5, 130-135.

[7] Gebauer, R. (2004) Mesophilic Anaerobic Treatment of Sludge from Saline Fish Farm Effluents with Biogas Production. Bioresource Technology, 93, 155-167. https://doi.org/10.1016/j.biortech.2003.10.024 
[8] Gebauer, R. and Eikebrokk, B. (2006) Mesophilic Anaerobic Treatment of Sludge from Salmon Smolt Hatching. Bioresource Technology, 97, 2389-2401. https://doi.org/10.1016/j.biortech.2005.10.008

[9] Kafle, G.K., Kim, S.H. and Sung, K.I. (2013) Ensiling of Fish Industry Waste for Biogas Production: A Lab Scale Evaluation of Biochemical Methane Potential (BMP) and Kinetics. Bioresource Technology, 127, 326-336. https://doi.org/10.1016/j.biortech.2012.09.032

[10] Nges, I., Mbatia, B. and Bjørnsson, L. (2012) Improved Utilization of Fish Waste by Anaerobic Digestion Following Omega-3 Fatty Acids Extraction. Journal of Environmental Management, 110, 159-165. https://doi.org/10.1016/j.jenvman.2012.06.011

[11] Solli, L., Bergersen, O., Sørheim, R. and Briseid, T. (2014) Effects of a Gradually Increased Load of Fish Waste Silage in Co-Digestion with Cow Manure on Methane Production. Waste Management, 34, 1553-1559. https://doi.org/10.1016/j.wasman.2014.04.011

[12] VDI 4630 (2016) Fermentation of Organic Materials-Characterisation of the Substrate, Sampling, Collection of Material Data, Fermentation Tests.

[13] Eiroa, M., Costa, J.C., Alves, M.M., Kennes, C. and Veiga, M.C. (2012) Evaluation of the Biomethane Potential of Solid Fish Waste. Waste Management, 32, 1347-1352. https://doi.org/10.1016/j.wasman.2012.03.020

[14] Al-Zuahiri, F., Pirozzi, D., Ausiello, A., Florio, C., Turco, M., Micoli, L., Zuccaro, G. and Toscano, G. (2015) Biogas Production from Solid State Anaerobic Digestion for Municipal Solid Waste. Chemical Engineering Transactions, 43, 2407-2412.

[15] Motte, J.-C., Escudié, R., Bernet, N., Delgenes, J.-P., Steyer, J.-P. and Dumas, C. (2013) Dynamic Effect of Total Solid Content, Low Substrate/Inoculum Ratio and Particle Size on Solid-State Anaerobic Digestion. Bioresource Technology, 144, 141-148. https://doi.org/10.1016/j.biortech.2013.06.057

[16] (2010) Guide to Biogas from Production to Use. Fachagentur Nachwachsende Rohstoffe e.V. (FNR). http://www.fnr.de

[17] Bouallagui, H., Lahdheb, H., Ben Romdan, E., Rachdi, B. and Hamdi, M. (2008) Improvement of Fruit and Vegetable Waste Anaerobic Digestion Performance and Stability with Co-Substrates Addition. Journal of Environmental Management, 90, 1844-1849. https://doi.org/10.1016/j.jenvman.2008.12.002

[18] Switzenbaum, M., Giraldo, S., Gomez, E. and Hichey, R.F. (1990) Monitoring of the Anaerobic Methane Fermentation Process. Enzyme and Microbial Technology, 12, 722-730. https://doi.org/10.1016/0141-0229(90)90142-D

[19] Callaghan, F.J., Wasea, D.A.J., Thayanithya, K. and Forster, C.F. (2002) Continuous Co-Digestion of Cattle Slurry with Fruit and Vegetable Wastes and Chicken Manure. Biomass Bioenergy, 27, 71-77. https://doi.org/10.1016/S0961-9534(01)00057-5

[20] Sluiter, A., Hames, B., Ruiz, R., Scarlata, C., Sluiter, J. and Templeton, D. (2008) Determination of Structural Carbohydrates and Lignin in Biomass. Laboratory Analytical Procedure, NREL, Colorado.

[21] Kafle, G.K., Kim, S.H. and Shin, B.S. (2012) Anaerobic Digestion Treatment for the Mixture of Chinese Cabbage Waste Juice and Swine Manure. Journal of Biosystems Engineering, 37, 58-64. https://doi.org/10.5307/JBE.2012.37.1.058

[22] Chen, X., Romano, R.T. and Zhang, R. (2010) Anaerobic Digestion of Food Wastes for Biogas Production. International Journal of Agricultural and Biological Engineering, 3, 61-72. 
[23] Kafle, G.K. and Kim, S.H. (2012) Evaluation of the Biogas Productivity Potential of Fish Waste: A Lab Scale Batch Study. Journal of Biosystems Engineering, 37, 302-313. https://doi.org/10.5307/JBE.2012.37.5.302

[24] Kassuwi, S.A.A., Mshandete, A.M. and Kivaisi, A.K. (2012) Anaerobic Co-Digestion of Biological Pre-Treated Nile Perch Fish Solid Waste with Vegetable Fraction of Market Solid Waste. ARPN Journal of Agricultural and Biological Science, 7, 1016-1031.

[25] Chen, Y., Cheng, J.J. and Creamer Kurt, S. (2007) Inhibition of Anaerobic Digestion Process: A Review. Bioresource Technology, 99, 4044-4064. https://doi.org/10.1016/j.biortech.2007.01.057

[26] Nalinga, Y. and Legonda, I. (2016) Experimental Investigation on Biogas Production from Anaerobic Co-Digestion of Water Hyacinth and Fish Waste. International Journal of Innovative Research in Technology and Science, 4, 1-8.

[27] Tomczak-Wandzel, R. and Levlin, E. (2012) Biogas Production from Fish Wastes in Co Digestion with Sewage Sludge. Gdańsk University of Technology, IVL Swedish Environmental Research Institute, Hammarby Sjöstadsverk, Dep. of Land and Water Resources Engineering, KTH, Royal Institute of Technology, Stockholm.

[28] Carvalho, L., Di Berardino, S. and Duarte, E. (2011) Anaerobic Digestion of a Fish Processing Industry Sludge. 16th European Biosolids and Organic Resources Conference.

[29] Shi, C. (2012) Potential Biogas Production from Fish Waste and Sludge. 